\title{
Transgenic Nicotiana tabacum seeds expressing the Mycobacterium tuberculosis Alanine- and Proline-rich antigen
}

\author{
Diego G. Módolo ${ }^{1,2}$ (D), Cynthia S. Horn³ ${ }^{3}$ José S. M. Soares ${ }^{1}$, José A. Yunes ${ }^{4}$, Leila M. Lima ${ }^{5}$, Sylvia M. de Sousa ${ }^{6}$ \\ and Marcelo Menossi ${ }^{1 *}$
}

\begin{abstract}
The glycoprotein APA (Alanine- and Proline-rich Antigen, a 45/47 kDa antigen complex, Rv1860) is considered as a major immunodominant antigen secreted by M. tuberculosis. This antigen has proved to be highly immunogenic in experimental models and humans, presenting a significant potential for further development of a new vaccine for tuberculosis. Glycosylation plays a key role in the immunogenicity of the APA protein. Because plants are known to promote post-translational modification such as glycosylation and to be one of the most economic and safe hosts for recombinant protein expression, we have over expressed the APA protein in transgenic tobacco plants aiming to produce a glycosylated version of the protein. Seeds are known to be a well-suited organ to accumulate recombinant proteins, due to low protease activity and higher protein stability. We used a seed-specific promoter from sorghum, a signal peptide to target the protein to the endoplasmic reticulum and ultimately in the protein storage vacuoles. We show that the recombinant protein accumulated in the seeds had similar isoelectric point and molecular weight compared with the native protein. These findings demonstrate the ability of tobacco plants to produce glycosylated APA protein, opening the way for the development of secure, effective and versatile vaccines or therapeutic proteins against tuberculosis.
\end{abstract}

Keywords: Mycobacterium tuberculosis, APA, 45/47 kDa, Tobacco, Alanine- and Proline-rich antigen, Seed

\section{Introduction}

Tuberculosis (TB), caused by Mycobacterium tuberculosis, is the first cause of death due to a single infectious agent in the world, leading to approximately 1.8 million deaths annually, and it was estimated that in 2015 there were 10.4 million TB cases globally (WHO 2017). HIV co-infection, which dramatically compromises host resistance, and the emergence of multidrug-resistance $M$. tuberculosis strains strongly collaborate for the increase in TB incidence (Maartens and Wilkinson 2007).

\footnotetext{
*Correspondence: menossi@lgfib.unicamp.br

${ }^{1}$ Laboratório de Genoma Funcional, Departamento de Genética,

Evolução, Microbiologia e Imunologia, Instituto de Biologia, Universidade Estadual de Campinas, Rua Monteiro Lobato, 255, Barão Geraldo, PO. Box: 6109, Campinas, SP 13083-970, Brazil

Full list of author information is available at the end of the article
}

The only available vaccine against $\mathrm{TB}$ is the live attenuated $M$. bovis strain Bacillus Calmette-Guérin (BCG), which provides effective protection against severe forms of childhood TB (meningeal and miliary TB). However, it fails to protect against the most frequent occurrence of the disease, pulmonary TB, in adults, and has not reduced the global burden of TB (Colditz et al. 1994; Fine 2001). Moreover, the use of a live vaccine (BCG) has the risk of developing pathologic effects in immunocompromised individuals (Norouzi et al. 2012). Therefore, better $\mathrm{TB}$ vaccines are urgently needed.

Antigenic proteins actively secreted during $M$. tuberculosis growth are the best suited targets to develop a new subunit vaccine against TB (Andersen 1994; Garapin et al. 2001; Kumar et al. 2003; Ferraz et al. 2004; Sable et al. 2011; Carlétti et al. 2013). Alanine- and Proline-rich Antigen (APA), also known as a $45 / 47 \mathrm{kDa}$ 
antigen complex, is a highly immunogenic glycoprotein secreted by the M. tuberculosis complex (Laqueyrerie et al. 1995; Berrêdo-Pinho et al. 2011). Despite the APA migration in SDS-PAGE gel shows bands of $45 / 47 \mathrm{kDa}$, this antigen when analyzed by mass spectrometry has a molecular weight of approximately $28 \mathrm{kDa}$, with the high percentage of proline and the presence of carbohydrates found in APA causing an abnormal migration on SDS-PAGE (Dobos et al. 1996; Horn et al. 1999). The $45 \mathrm{kDa}$ band observed in SDS-PAGE can be due to the presence of truncated APA protein molecules, with a C-terminal modification, that are co-purified with the $47 \mathrm{kDa}$ protein (Romain et al. 1999), and other study describes that the presence of the $45 \mathrm{kDa}$ band may be due to a differentiation in the glycosylation pattern of this protein (Lara et al. 2004).

The post-translational modification of $M$. tuberculosis APA antigen includes a complex O-mannosylation of Thr residues in $\mathrm{N}$ - and $\mathrm{C}$-terminal domains of the protein (Dobos et al. 1996), specifically, multiple $\alpha(1,2)$ mannose residues such as mannose, mannobiose, mannotriose were identified in Thr49, Thr57, Thr66 and Thr316 (Dobos et al. 1995; 1996). Moreover, an additional glycosylation of one, two or three hexoses between Thr313, Thr315, Thr316 and Thr318 has been observed (Smith et al. 2014). Mass spectrometry analysis show a variable pattern of mannosylation of APA molecules, and while a small number of native APA are not glycosylated, some have one to nine mannose residues, with a majority of glycoform bearing 6-8 mannose residues (Horn et al. 1999).

The absence or low levels of glycosylation, as demonstrated in the recombinant expression of APA in E. coli and $M$. smegmatis, respectively, leads to a great reduction in its immunological properties when compared with the native (glycosylated) protein, suggesting that glycosylation is essential to keep the immune activity of the APA antigen (Horn et al. 1999).

APA has been described as an adhesion molecule that interacts with the surfactant protein $\mathrm{A}$ in the lung, and it has been observed that this interaction is dependent on the glycosylation of APA (Ragas et al. 2007). Similarly, APA is considered a fibronectin attachment protein (FAP) which binds to bladder tumour cells, having an important role in the treatment of bladder cancer, being quite effective as an alternative therapy to BCG for the treatment of this disease (Sinn et al. 2008). Furthermore, monoclonal antibody against APA has been previously shown to abrogate the attachment and internalization of BCG by human bladder tumour cells, and the stable binding of BCG to bladder mucosa via FAP was necessary for the expression of BCG-induced anti-tumour activity (Kuroda et al. 1993; Zhao et al. 2000). Thus, the glycosylation and the fibronectin-binding domain could reinforce its interaction with the host.

Transgenic plants present enormous potential as a costeffective and safe platform for large scale production of vaccines and therapeutic proteins (Hefferon 2012). Various antigens have been successfully expressed in plants and have been shown to retain their native functionalities (Scissum Gunn et al. 2012). The production of vaccines against TB in plants has increased over the years, and recent studies have demonstrated the efficient expression of the early secretory antigenic target (ESAT-6) in plant cells (Zelada et al. 2006; Dorokhov et al. 2007; Zeng et al. 2008; Lakshmi et al. 2013), indicating plants are able to produce $M$. tuberculosis antigens.

The ability of plant cells to promote post-translational processing makes this model even more interesting than those based in prokaryotes (Bednarek and Raikhel 1992). The glycosylation of proteins has several functions, such as the maintenance of the three-dimensional structure and increased stability (Benz and Schmidt 2002; Lee et al. 2015). Plants have a wide range of enzymes involved in glycosylation (Strasser 2016). The pattern of protein glycosylation performed by plant cells differs slightly from that observed in human cells. The first stage of protein glycosylation is similar in all eukaryotic organisms, with the binding of an oligosaccharide precursor $\mathrm{Man}_{3} \mathrm{GlcNAc}_{2}$ in the endoplasmic reticulum (ER). The nascent $\mathrm{N}$-glycan is then processed by enzymes contained in the Golgi apparatus and these enzymes differ between plants, mammals, insects and yeasts, leading to a differentiation of the oligosaccharide structure (Peters and Stoger 2011). In plants, $N$-glycosylation comprises the addition of an $\alpha(1,3)$ fucose and a $\beta(1,2)$ xylose in the core structure, while in humans an $\alpha(1,6)$ fucose, $\beta$ $(1,4)$ galactose and $N$-acetylneuraminic acid is added to the glycoconjugate structure. In insect cells, the glycoconjugate has a smaller core of $\mathrm{N}$-glycans, with low sialylation, while yeasts have a completely different pattern, with only mannose-containing glycan (Strasser 2016).

Regarding O-glycosylation, plants transfer only one GlcNAc to Ser/Thr residues (O-GlcNAcylation), in the same way as in mammals. In addition, plants may add a galactose (Gal) to serine residues and arabinose chains (Ara) to hydroxyproline residues (Strasser 2016). Although plant-specific N-glycans, when injected subcutaneously, do not cause any adverse effects and no alteration of the immune response in humans (McCormick et al. 2008), alternatives are being developed to humanize the glycosylation pattern in plants when necessary, as the knockout of genes encoding enzymes responsible for the addition of specific plants glycans (Peters and Stoger 2011). Tobacco is a model system for recombinant protein production and is the 
most used species for the production of recombinant proteins at the laboratory scale (Cramer et al. 1999; Fischer and Emans 2000). The main advantages of tobacco include: advanced technology of gene transfer and expression, production of a high amount of seeds, which in turn also allows a fast scale-up of the number of transgenic plants in just a few generations (when the gene integration is stable), the availability of infrastructure for large-scale processing, and last, but not least, tobacco it is not used as food (Fischer and Emans 2000).

Seeds are the organ of choice to direct the expression of recombinant proteins when it is desirable to accumulate large amounts of proteins. They are designed for the synthesis and storage of proteins, giving an advantage over green tissues and tubers, in which the protein content is lower (De Jaeger et al. 2002; Shukla and Thömmes 2010). Moreover, seeds have low levels of non-enzymatic hydrolysis and protein degradation (Fischer et al. 2009). Therefore, recombinant proteins accumulated in the seeds remain stable and functional for several years, even after storage at room temperature (Stöger et al. 2000; Foley et al. 2011).

It is of great interest to develop systems that produce recombinant proteins with biological properties similar to native proteins (Woodard et al. 2004). Considering the relevance of glycosylation patterns for some proteins and also the seek of an efficient and safe production of recombinant proteins without human pathogens in a cost effective way, the use of transgenic plants is a good alternative (Ma et al. 2003).

Given the existence of a glycosylation system in plants, there is a possibility that the APA protein produced in transgenic plants, such as tobacco, would have a glycosylation profile, probably different from mycobacteria, but that could present in vivo immunogenic activity. Therefore, the focus of this study was to produce transgenic tobacco plants that express the recombinant protein APA in their seeds. For this purpose, we used an expression vector with a seed-specific promoter for $\gamma$-kafirin from sorghum, followed by a signal peptide of $\alpha$-coixin to direct the recombinant protein to the endoplasmic reticulum (for protein glycosylation in the secretory pathway) and consequent accumulation of APA in protein storage vacuoles. We obtained the partially purified recombinant protein and we present evidence of recombinant protein glycosylation due to its affinity for binding to Concanavalin $\mathrm{A}$ and due to the presence of multiple isoforms in two-dimensional electrophoresis. This open new venues for the production of a recombinant vaccine for tuberculosis.

\section{Materials and methods}

\section{Plant materials and culture conditions}

Nicotiana tabacum SR1 (Maliga et al. 1973) seeds were surface-sterilized in $70 \%$ ethanol for $1 \mathrm{~min}$ and rinsed three times with sterile distilled water. Then they were incubated in $1 \% \mathrm{NaOH}$ for 20 min and rinsed 5 times with sterile distilled water. Sterilized seeds were then germinated on MS medium (Murashige and Skoog 1962) containing sucrose $30 \mathrm{~g} / \mathrm{L}$, MS vitamin $1 \mathrm{~mL} / \mathrm{L}$ and Phytagel $2.5 \mathrm{~g} / \mathrm{L}$ in Petri dishes. Seedlings were transferred to glass pots with the same culture medium for 3 weeks at $25{ }^{\circ} \mathrm{C}$ with a photoperiod of $16 \mathrm{~h}$ day/ light.

\section{Construction of plant expression vector}

The APA coding region (GenBank Accession Number $\mathrm{X} 80268)$ was fused to the $\alpha$-coixin signal peptide from Coix lacryma-jobi to target the recombinant protein to the endoplasmic reticulum (Ottoboni et al. 1993). The DNA encoding the $\alpha$-coixin signal peptide (named PSC) was produced by annealing two synthetic oligonucleotides: PS1 (5'-CATGGCTACCAAGATATTTGC CCTCCTTGTGCTCCTTGCTCCTTGTGCTCCTTG CTCTTTCAGCGAGCGCTACAACTGCG-3') and PS2 (5'-CGCAGTTGTAGCGCTCGCTGAAAGAGCAAG GAGCACAAGGAGGGCAAATATCTTGGTAGC-3'), giving rise to a fragment with $5^{\prime} \mathrm{NcoI}$ overhang and a $3^{\prime}$ blunt end. The APA $871 \mathrm{bp}$ fragment was amplified by PCR using the primers TBLEFT (5'-GATCCGGAGCCA GCGCC-3') and TBRIGHT (5'-CGGGATCCCGTCAG GCCGGTAAGGTCCGCT-3'; BamHI site underlined) using as template the pLA34 plasmid containing the APA sequence (Laqueyrerie et al. 1995). The PSC fragment was fused to the blunt end of the amplified $A P A$ fragment, resulting in the fragment named PSC-APA, containing a $5^{\prime} \mathrm{NcoI}$ overhang, which was later digested with BamHI. The PSC-APA fragment was inserted into the pRT-PGK (Leite et al. 2000) vector previously digested with $N c o I / B a m H I$, giving rise to the plasmid pRT-PGK-PSC-APA. Subsequently, a HindIII fragment of pRT-PGK-PSC-APA containing the expression cassette with the seed specific $\gamma$-kafirin promoter (PGK) from sorghum (de Freitas et al. 1994) and the $35 \mathrm{~S}$ terminator was inserted into the HindIII site of pCambia 3301 vector (CAMBIA, Australia), giving rise to the plasmid pCam-PSC-APA, which additionally has, in the T-DNA, the $B A R$ gene responsible to encode the phosphinothricin- $\mathrm{N}$-acetyl transferase enzyme, that confers resistance to the herbicide phosphinothricin (PPT) to plants, and the reporter GUS gene, encoding $\beta$-glucluronidase, both under control of the constitutive promoter $35 \mathrm{~S}$ (Fig. 1). The pCam-PSC-APA plasmid was transferred to 


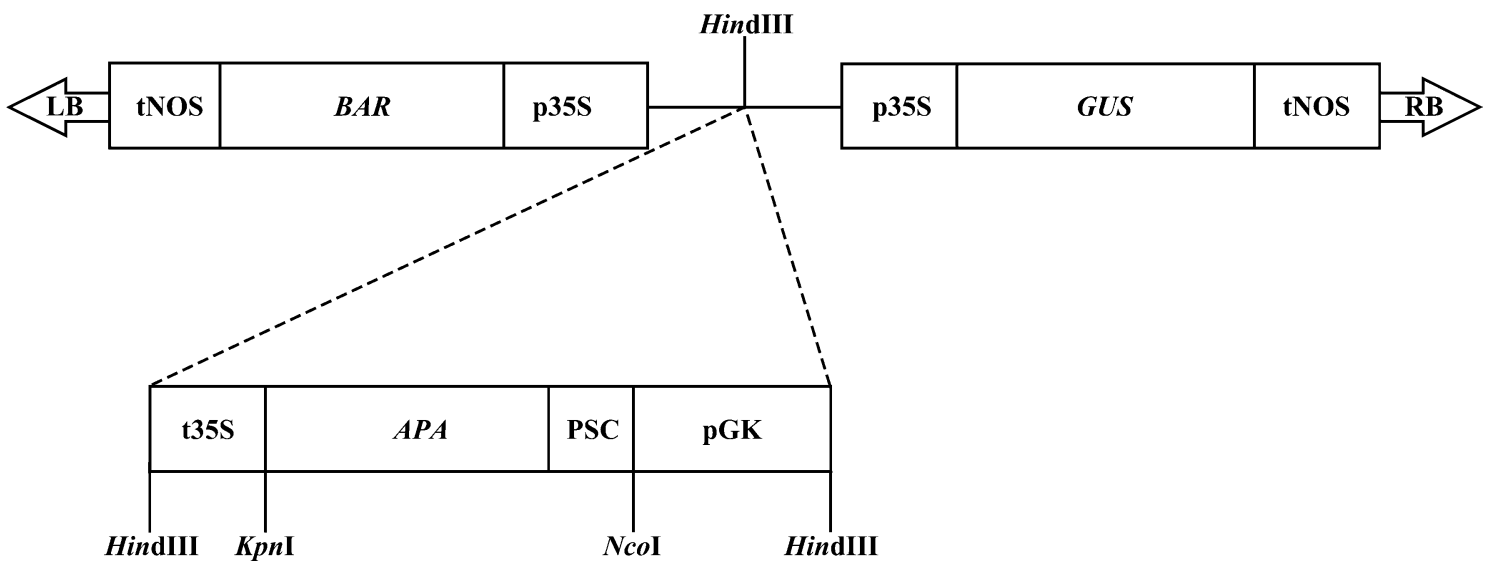

Fig. 1 Structure of the pCam-PSC-APA vector used for tobacco genetic transformation. The M. tuberculosis APA gene (APA) was fused with a-coixin signal peptide (PSC) under the control of $\gamma$-kafirin promoter ( $\mathrm{pGK}$ ) and the $35 \mathrm{~S}$ terminator ( $\mathrm{t} 35 \mathrm{~S}$ ). The BAR and GUS genes are under the control of the 355 promoter (p35S) and the terminator from the NOS gene (tNOS). LB and RB are the borders of the expression vector

Agrobacterium tumefaciens GV3101 (Koncz and Schell 1986) by thermal shock.

\section{Plant transformation}

The transformed Agrobacterium was cultivated in $20 \mathrm{~mL}$ of LB broth with antibiotics $(100 \mathrm{mg} / \mathrm{L}$ rifampicin, $60 \mathrm{mg} / \mathrm{L}$ gentamicin and $100 \mathrm{mg} / \mathrm{L}$ kanamycin) at $28{ }^{\circ} \mathrm{C}$ until reaching an $\mathrm{OD}_{600}$ of 0.8 . After brief centrifugation, the cell pellet was resuspended in $1 \mathrm{~mL}$ of $0.85 \% \mathrm{NaCl}$ solution at and kept at room temperature before use.

Leaves from tobacco plants grown as described above were cut in 0.5 to $1.0 \mathrm{~cm}^{2}$ fragments and then were cultured in $20 \mathrm{~mL}$ of INFTAB medium (MS salts, $100 \mathrm{mg} / \mathrm{L}$ myo inositol, $1 \mathrm{mg} / \mathrm{L}$ calcium pantothenate, $1 \mathrm{mg} / \mathrm{L}$ nicotinic acid, $1 \mathrm{mg} / \mathrm{L}$ pyridoxine, $1 \mathrm{mg} / \mathrm{L}$ thiamine, and $0.01 \mathrm{mg} / \mathrm{L}$ biotin) with $200 \mu \mathrm{L}$ of Agrobacterium GV3101 containing the pCam-PSC-APA construct. After $48 \mathrm{~h}$ in the dark at $25^{\circ} \mathrm{C}$, leaf fragments were transferred to solid INFTAB medium containing $1 \mathrm{mg} / \mathrm{L}$ benzylaminopurine, $300 \mathrm{mg} / \mathrm{L}$ timentin and $5 \mathrm{mg} / \mathrm{L}$ phosphinothricin. Shoots were generated after 4-5 weeks, isolated and transferred to MS medium with $300 \mathrm{mg} / \mathrm{L}$ timentin and $5 \mathrm{mg} / \mathrm{L}$ phosphinothricin for root formation. Tobacco plants with roots were transferred to a greenhouse after 3-4 weeks for acclimatization. After verifying the genomic integration of the APA by PCR and the expression of the GUS transgene, the seeds were collected for further analysis.

\section{Detection of APA gene in transgenic plants}

Genomic DNA was isolated from transformed and wildtype tobacco leaves by the CTAB method (Murray and Thompson 1980). The presence of the APA gene in the genomic DNA was confirmed by PCR using the forward primer TBLEFT and the reverse primer TBRIGHT.

\section{Detection of the recombinant APA protein from transgenic tobacco plants}

For protein extraction, $50 \mathrm{mg}$ of transgenic seeds were homogenized by grinding in a mortar with $1 \mathrm{~mL}$ of extraction buffer (50 mM Tris-HCl, pH 8.0, 2 mM EDTA, $5 \mathrm{mM}$ benzamidine, $5 \mathrm{mM}$ dithiothreitol, $0.5 \%$ Triton $\mathrm{X}-100)$. Homogenates were centrifuged at $10,000 \times g$ for $10 \mathrm{~min}$ at $4{ }^{\circ} \mathrm{C}$. The supernatant was collected and mixed with hexane $(1: 1 \mathrm{v} / \mathrm{v})$ and centrifuged at $15,000 \times g$ for $15 \mathrm{~min}$ at $4{ }^{\circ} \mathrm{C}$. The lower phase was collected and protein concentration was determined using the BSA Protein Assay Kit (Pierce, USA).

An aliquot of $40 \mu \mathrm{g}$ of the soluble proteins was mixed with sample buffer (125 mM Tris $\mathrm{HCl}, 4 \%$ SDS, $10 \%$ $\beta$-mercaptoethanol, $20 \%$ glycerol, $0.04 \%$ bromophenol blue, $\mathrm{pH}$ 6.8) and the samples were denatured in water at $95^{\circ} \mathrm{C}$ for $5 \mathrm{~min}$. The samples were separated by denaturing SDS-PAGE using a $12 \%$ polyacrylamide gel. Proteins were electrophoretically transferred to a nitrocellulose membrane (Hybond-C Extra, GE Healthcare, USA) using a Trans-blot SD semi-dry transfer cell (Bio-Rad, USA). Membranes were blocked with TBS $(25 \mathrm{mM}$ Tris- $\mathrm{HCl}$, $150 \mathrm{mM} \mathrm{NaCl}, 2 \mathrm{mM} \mathrm{KCl}, \mathrm{pH}$ 7.4) with $10 \%$ non-fat dry milk overnight at $4{ }^{\circ} \mathrm{C}$. Then, membranes were incubated with gentle agitation for $2 \mathrm{~h}$ in $20 \mathrm{~mL}$ of TBS with 5\% non-fat dry milk with an anti-APA rabbit polyclonal antibody, kindly provided by Dr. G. Marchal (Pasteur Institute, France) (Laqueyrerie et al. 1995), diluted 1:4000. Membranes were washed three times with TBS-T (TBS, $0.005 \%$ Tween 20 ) and three times with TBS, followed by an incubation with a 1:20,000 dilution of anti-rabbit IgG conjugated with peroxidase (Pierce, USA) in $20 \mathrm{~mL}$ TBS with $5 \%$ of non-fat dry milk for $2 \mathrm{~h}$ with gentle agitation. Then, membranes were washed three times with TBS-T 
and TBS. The chemiluminescent signal was developed with Super Signal ${ }^{\circledR}$ West Pico (Pierce, USA) and the signal was revealed using X-ray films. The native APA protein from $M$. tuberculosis, kindly provided by C. Horn (FIOCRUZ, Brazil) (Horn et al. 1999) was used as positive control, and protein from non-transformed tobacco seeds were used as negative control.

\section{Concanavalin binding assay}

The affinity of the recombinant APA protein for concanavalin was determined by affinity chromatography. ConA Sepharose (GE Healthcare, DE) resin was washed in equilibrium buffer $(20 \mathrm{mM}$ Tris- $\mathrm{HCl}, 0.5 \mathrm{M} \mathrm{NaCl}, \mathrm{pH}$ 7.4) and $5 \mathrm{~mL}$ of resin were incubated with $100 \mathrm{~mL}$ of soluble proteins overnight at $4{ }^{\circ} \mathrm{C}$ with gentle agitation in a blood homogenizer. The mixture was transferred to an Econo-Column chromatography column of $1.5 \times 10 \mathrm{~cm}$ (Bio-Rad, USA) and washed with $50 \mathrm{~mL}$ of equilibrium buffer, using a flow rate of $1 \mathrm{~mL} / \mathrm{min}$ to elute non-bound protein. Bound proteins were eluted with $0.01 \mathrm{M}$ borate buffer at $\mathrm{pH} 7.4$ and $0.1 \mathrm{M}$ borate buffer at $\mathrm{pH} 7.4$ under continuous flow $(30 \mathrm{~mL} / \mathrm{h})$. Eluted protein fractions were collected and stored at $-20{ }^{\circ} \mathrm{C}$ until used for silver-staining SDS-PAGE and 2D electrophoresis western blot.

\section{Two-dimensional electrophoresis}

For two-dimensional electrophoresis, $25 \mu \mathrm{g}$ of concanavalin-bound proteins obtained above were solubilized in $125 \mu \mathrm{L}$ of rehydration buffer containing $8 \mathrm{M}$ urea, $2 \%$ CHAPS, $2 \%$ tributylphosphine (TBP), $1 \%$ carrier ampholytes, $0.01 \%$ bromophenol blue (w/v). Samples were incubated for $1 \mathrm{~h}$ at room temperature and loaded onto an immobilized $\mathrm{pH}$ gradient (IPG) strip, $\mathrm{pH}$ 3-10. Isoelectric focusing was performed on a Protean ${ }^{\circledR}$ IEF cell (Bio-Rad, USA) with maximum current of $50 \mu \mathrm{A} /$ strip. Focusing parameters used for IPG strips in the $\mathrm{pH}$ range 3-10 were: active rehydration $(50 \mathrm{~V})$ for $11 \mathrm{~h}$; step 1 -linear gradient from 1 to $250 \mathrm{~V}$ over $20 \mathrm{~min}$; step 2-linear gradient from 250 to $4000 \mathrm{~V}$ over $2 \mathrm{~h}$; step 3-constant $4000 \mathrm{~V}$ until $18,500 \mathrm{Vh}$ was achieved. The strips were then incubated for $15 \mathrm{~min}$ in equilibration buffer $(50 \mathrm{mM}$ Tris-HCl, $6 \mathrm{M}$ urea, 30\% glycerol, $2 \%$ SDS, pH 8.8) containing $25 \mathrm{mM}$ dithiothreitol with gentle agitation, followed by incubation for $15 \mathrm{~min}$ in equilibration buffer containing $55 \mathrm{mM}$ iodoacetamide. Then, the strips were transferred to a $12 \%$ SDS polyacrylamide gel $(1.5 \mathrm{~mm}$ thick) and the focalized proteins were separated by electrophoresis, in standard Laemmli buffer at $100 \mathrm{~mA} / \mathrm{gel}$, until the tracking dye left the gel. The recombinant protein was detected by western blot as described previously.

\section{Results}

Production of transgenic plants containing the APA gene The APA gene from $M$. tuberculosis was amplified by PCR and linked to a synthetic $\alpha$-coixin signal peptide DNA sequence to enable the targeting of the recombinant protein to the endoplasmic reticulum and accumulation in protein storage vacuoles. This fusion, named PSC-APA, was inserted into the PRT-PGK plasmid under the control of the $\gamma$-kafirin seed-specific promoter and the $35 \mathrm{~S}$ terminator. The expression cassette was cut from this plasmid and inserted into the plant expression vector pCambia 3301. This vector, named pCam-PSC-APA (Fig. 1), was introduced into Agrobacterium tumefaciens GV3101 to produce transgenic plants. We selected, for further analysis, seven independent plants with no visible morphological changes that grew under a selection media containing phosphinothricin, indicating the tobacco genetic transformation by the expression of the $B A R$ gene present in T-DNA.

The presence of the APA coding sequence in these plants was confirmed by PCR of genomic DNA using APA gene specific primers (Fig. 2). The positive transgenic plants were identified by the presence of an $871 \mathrm{bp}$ DNA fragment. The transgenic plants showed the same size fragment observed in the sample containing the pCam-PSC-APA vector used as positive control. A non-specific PCR product of approximately $650 \mathrm{bp}$ was observed in all plants, including the wild-type, nontransformed plants (Fig. 2). All transgenic APA plants were also positive for GUS gene expression, present in the T-DNA, while wild-type plants showed no GUS activity (data not show).

\section{Detection of recombinant APA protein in transgenic tobacco plants}

Total soluble proteins from seeds of the seven transgenic plants selected by PCR and GUS activity were tested to detect the presence of the recombinant APA protein by western blot, using a rabbit anti-APA polyclonal antibody. As shown in Fig. 3, the native APA protein from $M$. tuberculosis, used as positive control, showed the characteristic 45 and $47 \mathrm{kDa}$ bands, as described previously (Romain et al. 1993). The presence of a $47 \mathrm{kDa}$ band was observed in the transgenic plant samples, indicating that the recombinant APA protein was similar to the APA protein from M. tuberculosis (Fig. 3). Additionally, it is possible to visualize a band below $47 \mathrm{kDa}$ with approximately $46 \mathrm{kDa}$ (Fig. 3, lanes 4, 7 and 8) when lower amounts of recombinant protein was detected, while in the plant with higher recombinant protein production the two bands appear to overlap due to the strong signal of the detected protein (Fig. 3, lane 9). The events with 


\section{a}

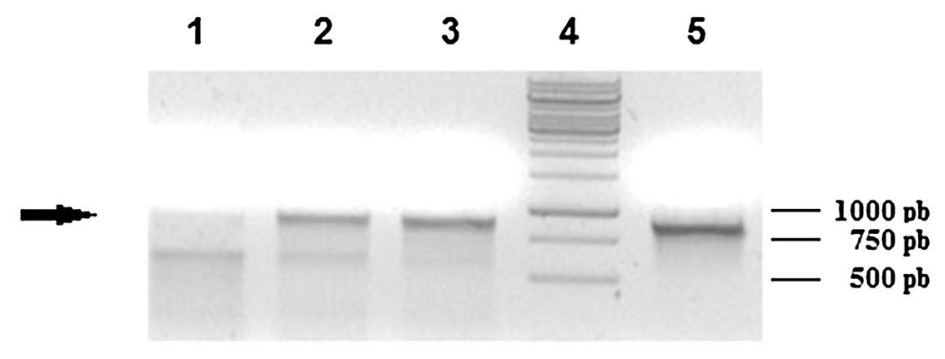

b

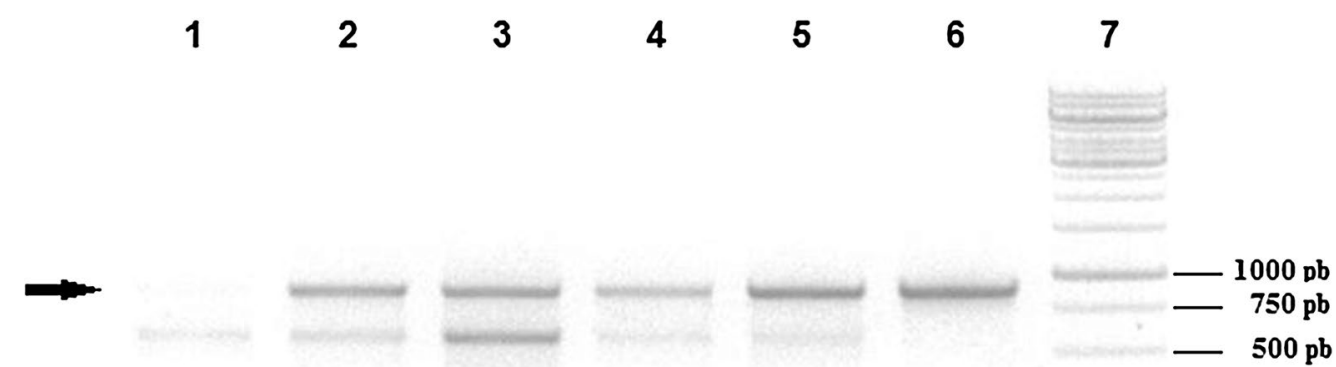

Fig. 2 Detection of the APA gene in transgenic tobacco plants. Genomic DNA was amplified with specific primers to detect an 871 bp fragment (indicated by an arrow) corresponding to the APA gene. a Lane 1: negative control; Lanes 2 and 3: transgenic plants; Lane 4: DNA size marker; Lane 5: positive control. b Lane 1: negative control; Lanes 2-5: transgenic plants; Lane 6: positive control; Lane 7: DNA size marker. The negative control was the amplification of the genomic DNA from wild-type plants; the positive control was the amplification from pCam-PSC-APA plasmid DNA and the DNA size marker used was the Gene Ruler 1 kB (Fermentas, USA)

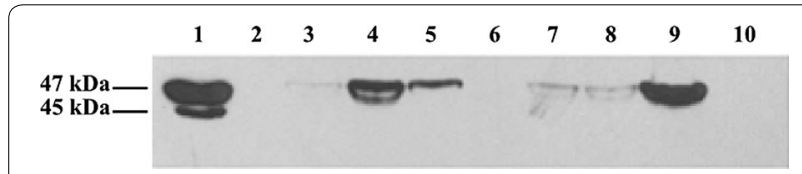

Fig. 3 Detection of the APA recombinant protein in tobacco plants. An anti-APA polyclonal antibody was used to detect the APA protein. Lane 1: $500 \mathrm{ng}$ of APA purified from M. tuberculosis as positive control. Lane 2: Empty lane; Lanes 3-9: protein extracts from transgenic seeds. Lane 10: protein extract from wild-type Nicotiana tabacum seeds (negative control). The positions of the expected bands of 47 and $45 \mathrm{kDa}$ are indicated on the left

the highest expression were T-APA1 and 4 (Fig. 3, lanes 9 and 4 respectively). No band corresponding to the APA was detected in the protein extract from the wild-type $N$. tabacum, indicating the high specificity of the anti-APA antibody utilized in this work (Fig. 3, lane 10).

\section{Concanavalin binding assay}

Recombinant APA from transgenic tobacco seeds was semi-purified by affinity chromatography using ConA Sepharose, a resin containing concanavalin that binds glycoproteins. Protein extracts from transgenic tobacco seeds were applied to the resin, and aliquots of $1 \mathrm{~mL}$ were collected. The presence of the recombinant APA protein and contaminating proteins in these fractions was determined by silver-staining SDS-PAGE (Fig. 4), due the high sensitivity of this technique to stain proteins even in low amounts. We observed two bands with approximate sizes of 46 and $47 \mathrm{kDa}$, corresponding to recombinant APA, and other bands with approximately 25, 30, $37 \mathrm{kDa}$ which are probably contaminating proteins from tobacco seeds that were also co-eluted with APA (Fig. 4, lane 3). It is also shown that the APA control protein has some contaminant proteins, probably due to incomplete purification of the native protein from M. tuberculosis. Although the APA protein eluted in ConA affinity chromatography presented a low amount of contaminating proteins when compared to the protein extract of transgenic tobacco seeds, future steps of purification polishing can be applied in order to obtain a recombinant protein with a higher degree of purity.

\section{Two-dimensional electrophoresis}

To check the heterogeneity of the recombinant APA protein and its isoforms, the semi-purified protein fraction shown in Fig. 4, after ConA Sepharose chromatography, 


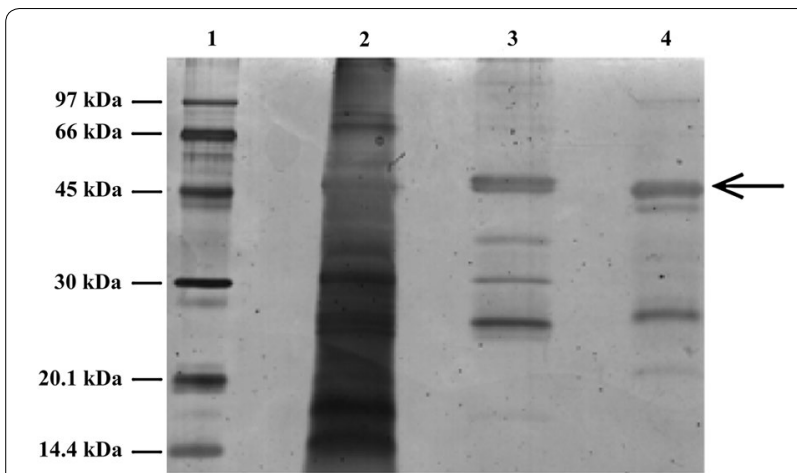

Fig. 4 Silver-staining SDS-PAGE from tobacco proteins purified with concanavalin affinity chromatography. Lane 1: Low molecular weight marker (GE Healthcare, UK); lane 2: total soluble proteins from transgenic tobacco seeds (event T-APA 1); lane 3: eluted fraction after ConA Sepharose purification; lane 4: 500 ng of purified native APA protein from M. tuberculosis. The position of the recombinant APA protein is indicated with an arrow

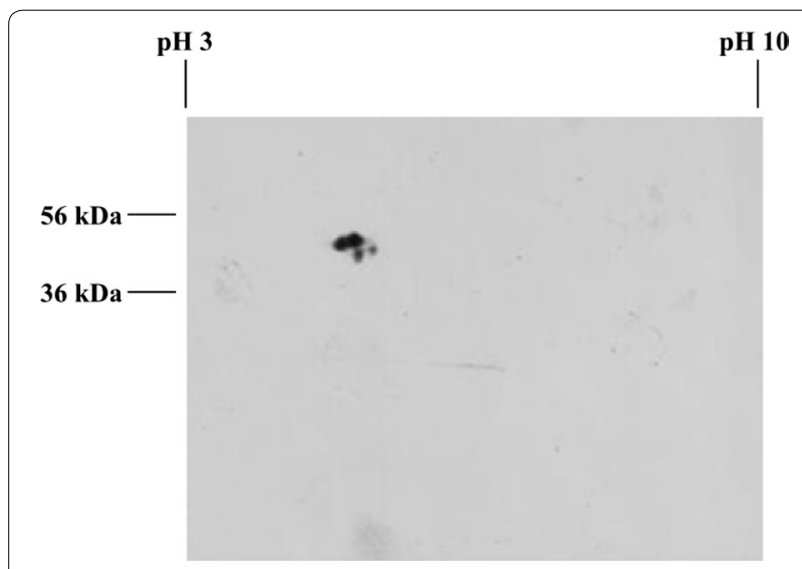

Fig. 5 Western blot of two-dimensional electrophoresis of affinity chromatography purified recombinant APA protein. The electrofocusing was performed on a linear IPG (pH 3.0 to 10.0). The $\mathrm{pH}$ gradient is indicated on the top of the figure and the molecular size marker on the left

was analyzed by $2 \mathrm{D}$ electrophoresis. The identification of the recombinant protein was performed by western blot using a polyclonal antibody against the $M$. tuberculosis APA protein (Fig. 5). Four spots were observed, indicating the presence of two isoforms in the $47 \mathrm{kDa}$ and $46 \mathrm{kDa}$ recombinant proteins, with distinct isoelectric points between 4.0 and 5.0 (Fig. 5). This result confirmed the presence of the 47 and $46 \mathrm{kDa}$ protein complex in the SDS-PAGE western blot (Fig. 3) and in the fraction purified by affinity chromatography, indicating that the recombinant APA protein has more than one isoform, probably because of changes in the glycosylation pattern.

\section{Discussion}

The low efficacy of BCG vaccine in protecting against pulmonary $\mathrm{TB}$ in adults and the risk of immunocompromised individuals developing the disease by BCG vaccination are major drivers to the development of an effective subunit vaccine against $M$. tuberculosis. One way to obtain these antigens is the expression of recombinant proteins in transgenic organisms. Plants are an interesting alternative due to their advantages compared to other systems used for the production of recombinant proteins, because of their lower costs for cultivation when compared with expensive growth media used to mammalian and insect cells cultivation, the absence of contamination of the product by mammalian pathogens and bacterial endotoxins and their scalability (Ma et al. 2003; Schillberg et al. 2003).

Previous studies with a plantibody expressed in tobacco seeds found that this species is able to glycosylate recombinant proteins (Hernández-Velázquez et al. 2015). The plantibody contained structures of high-mannose and predominantly type-complex $\mathrm{N}$-glycans, indicating that a high proportion of molecules modified with $\alpha$ (1.3) fucose and $\beta$ (1.2) xylose. Additionally, a high mannose type $\mathrm{N}$-glycan profile of five to nine mannoses residues was found, and the most prevalent modification was the presence of seven mannose residues in the recombinant protein, with a oligomannoside structure proportion of $52 \%$ of the plantibody N-glycans (Hernández-Velázquez et al. 2015).

In this study we produced transgenic tobacco plants that were able to accumulate recombinant APA protein. Recombinant APA proteins with $46 / 47 \mathrm{kDa}$ were detected by SDS-PAGE western blot, and four spots were observed when separated in two-dimensional electrophoresis immunobloting, similarly as described previously in protein extracts from $M$. tuberculosis (González-Zamorano et al. 2009) and M. bovis BCG (Romain et al. 1993; Ragas et al. 2007).

The antigen APA is described as a Concanavalin A (ConA) binding protein due its affinity with ConA (Espitia et al. 1995; Lara et al. 2004; González-Zamorano et al. 2009), a lectin carbohydrate linker. We found evidences of glycosylation of the recombinant APA expressed in tobacco seeds due to the ability to bind ConA by affinity chromatography, demonstrating that the recombinant protein was glycosylated. Other glycosylated proteins found in plant seeds also have ConA affinity and were eluted together with the recombinant protein (Fig. 4) and were not detected by two-dimensional western blot using a specific anti-APA antibody (Fig. 5). Although we observed the binding of other proteins in the chromatography, the use of ConA affinity was effective for the partial purification of the APA antigen. 
Previous studies describe the $45 \mathrm{kDa}$ protein being a product derivative from a proteolytic action on the of $47 \mathrm{kDa}$ protein, which lacks a C-terminal glycosylated peptide (Romain et al. 1999). However, this statement has never been demonstrated definitely. Interestingly, the reduced number of glycans in the $45 \mathrm{kDa}$ protein drastically reduces its affinity for PSP-A (human pulmonary surfactant protein A), a C-type lectin (Ragas et al. 2007).

Interestingly, when the APA protein is expressed in $S$. lividans, the $45 / 47 \mathrm{kDa}$ proteins were observed in SDSPAGE (Lara et al. 2004), but the $45 \mathrm{kDa}$ form did not react with ConA, indicating that this recombinant protein form is glycosylated by sugars other than mannose or by a different configuration that is not recognized by ConA. Therefore, these authors suggested that even for the native $45 / 47 \mathrm{kDa}$ protein, the existence of two bands can be attributed due to differences in glycosylation of the same protein instead of a proteolytic action or C-terminal modification (Lara et al. 2004). In contrast to the S. lividans recombinant APA, the plant-made $46 / 47 \mathrm{kDa}$ protein had affinity for ConA, and the two bands were eluted together after the affinity chromatography, indicating that both forms were glycosylated with ConA binding glycans.

Regarding the $45 / 47 \mathrm{kDa}$ proteins expressed in S. lividans, these authors observed that the recombinant protein had the same isoelectric point, which differs from the native proteins pattern that migrate as several spots in 2D gel electrophoresis due to differences in their isoelectric points, caused by a diversity in glycosylation on native APA (Espitia et al. 1995; Lara et al. 2004). According to the results of our bi-dimensional gel electrophoresis followed by western blot, we estimated that the pI of the APA protein obtained from transgenic plants ranged from 4 to 5 . The presence of four spots from the $46 / 47 \mathrm{kDa}$ complexes suggests the presence of four isoforms of the protein. The presence of different APA isoforms in the native APA preparations has been extensively described for both 45 and $47 \mathrm{kDa}$ protein in bidimensional gel (Romain et al. 1993; Espitia et al. 1995; Ragas et al. 2007).

Taking into account that differences in protein glycosylation may lead to a different protein migration in both SDS-PAGE and bi-dimensional electrophoresis, we conclude that the presence of two different mass in SDS-PAGE and four spots in 2D western blot is due to a diverse glycosylation pattern of the recombinant plant APA. This pattern can also reflect a distinct number of mannose residues, as observed for the $\mathrm{N}$-glycosylation in tobacco seeds by Hernández-Velázquez et al. (2015). It is worth noting that the APA protein has two N-glycosylation sites (Asn-X-Ser/Thr) in its primary structure, which allows the presence of this type of glycosylation in this protein, in addition to the regions prone to O-glycosilation.

Many reports on plant-made vaccines for human and animal health (reviewed by Laere et al. 2016; Rybicki 2017) show the increased interest in the development of new strategies for the use of plants as bioreactor for antigen production. In spite of the differences in protein glycosylation between plants and others heterologous protein expression systems, a large number of plant-made antigens has been proposed in the literature. We have produced transgenic tobacco plants expressing a glycosylated APA protein that resembles the native protein. We emphasize that future characterization of the glycan structure of the plant made APA will be helpful to compare the structure and biological properties of native bacterial products to those obtained by recombinant DNA technology. Our data open new avenues for the production of a recombinant protein to be used for prevention against tuberculosis.

\section{Abbreviations}

APA: Alanine- and Proline-rich antigen; BCG: Bacillus Calmette-Guérin; Con A: Concanavalin A; ESAT-6: early secretory antigenic target; FAP: fibronectin attachment protein; MS: Murashige and Skoog medium; SDS-PAGE: Sodium dodecyl sulfate-polyacrylamide gel electrophoresis; TB: tuberculosis.

\section{Authors' contributions}

All authors read and approved the final manuscript.

\section{Author details}

${ }_{1}^{1}$ Laboratório de Genoma Funcional, Departamento de Genética, Evolução, Microbiologia e Imunologia, Instituto de Biologia, Universidade Estadual de Campinas, Rua Monteiro Lobato, 255, Barão Geraldo, PO. Box: 6109, Campinas, SP 13083-970, Brazil. ${ }^{2}$ Laboratório de Genética, Instituto Butantan, São Paulo, SP 05503-900, Brazil. ${ }^{3}$ Laboratório de Imunologia e Imunogenética de Doenças Infecciosas, Instituto Nacional de Infectologia Evandro Chagas, Fundação Oswaldo Cruz, Rio de Janeiro, RJ 21040-900, Brazil. ${ }^{4}$ Laboratório de Biologia Molecular, Centro Infantil de Investigações Hematológicas Dr Domingos A Boldrini, Campinas, SP 13083-210, Brazil. ${ }^{5}$ Departamento de Bioquímica e Biologia Molecular, Instituto Oswaldo Cruz, Fundação Oswaldo Cruz, Rio de Janeiro, RJ 21040-900, Brazil. ${ }^{6}$ Centro Nacional de Pesquisa de Milho e Sorgo, Empresa Brasileira de Pesquisa Agropecuária, Sete Lagoas, MG 35701-970, Brazil.

\section{Acknowledgements}

The authors thank Espaço da Escrita-Coordenadoria Geral da UniversidadeUNICAMP_for the language services provided. We also would like to thank B.Sc. Paula Regina Zacharias and Ph.D. Letícia Jungmann Cançado for their generous support. In memoriam thanks to Adilson Leite for the project's initiative and dedication to his students and works.

\section{Competing interests}

The authors declare that they have no competing interests.

Availability of data and materials

All data and materials are available from the corresponding author on reasonable request.

Consent for publication

Not applicable. 
Ethics approval and consent to participate Not applicable.

\section{Funding}

This research was supported by Conselho Nacional de Desenvolvimento Científico e Tecnológico (CNPq) [131420/2007-0] and Fundação de Amparo à Pesquisa do Estado de São Paulo (FAPESP) [2013/15576-5].

\section{Publisher's Note}

Springer Nature remains neutral with regard to jurisdictional claims in published maps and institutional affiliations.

Received: 18 June 2018 Accepted: 24 October 2018

Published online: 31 October 2018

\section{References}

Andersen P (1994) Effective vaccination of mice against Mycobacterium tuberculosis infection with a soluble mixture of secreted mycobacterial proteins. Infect Immun 62:2536-2544

Bednarek SY, Raikhel NV (1992) Intracellular trafficking of secretory proteins. Plant Mol Biol 20:133-150

Benz I, Schmidt MA (2002) Never say never again: protein glycosylation in pathogenic bacteria. Mol Microbiol 45:267-276

Berrêdo-Pinho M, Kalume DE, Correa PR, Gomes LHF, Pereira MP, da Silva RF, Castello-Branco LRR, Degrave WM, Mendonça-Lima L (2011) Proteomic profile of culture filtrate from the Brazilian vaccine strain Mycobacterium bovis BCG Moreau compared to M. bovis BCG Pasteur. BMC Microbiol 11:80. https://doi.org/10.1186/1471-2180-11-80

Carlétti D, Morais da Fonseca D, Gembre AF, Masson AP, Weijenborg Campos L, Leite LCC, Rodrigues Pires A, Lannes-Vieira J, Lopes Silva C, Bonato VLD, Horn C (2013) A single dose of a DNA vaccine encoding apa coencapsulated with 6,6'-trehalose dimycolate in microspheres confers long-term protection against tuberculosis in Mycobacterium bovis BCG-primed mice. Clin Vaccine Immunol 20:1162-1169. https://doi.org/10.1128/cvi.00148 $-13$

Colditz GA, Brewer TF, Berkey CS, Wilson ME, Burdick E, Fineberg HV, Mosteller $F$ (1994) Efficacy of BCG vaccine in the prevention of tuberculosis. Metaanalysis of the published literature. JAMA 271:698-702

Cramer CL, Boothe JG, Oishi KK (1999) Transgenic plants for therapeutic proteins: linking upstream and downstream strategies. Curr Top Microbiol Immunol 240:95-118

de Freitas FA, Yunes JA, da Silva MJ, Arruda P, Leite A (1994) Structural characterization and promoter activity analysis of the gamma-kafirin gene from sorghum. Mol Gen Genet 245:177-186

De Jaeger G, Scheffer S, Jacobs A, Zambre M, Zobell O, Goossens A, Depicker A, Angenon $G$ (2002) Boosting heterologous protein production in transgenic dicotyledonous seeds using Phaseolus vulgaris regulatory sequences. Nat Biotechnol 20:1265-1268. https://doi.org/10.1038/nbt755

Dobos KM, Swiderek K, Khoo KH, Brennan PJ, Belisle JT (1995) Evidence for glycosylation sites on the 45-kilodalton glycoprotein of Mycobacterium tuberculosis. Infect Immun 63:2846-2853

Dobos KM, Khoo KH, Swiderek KM, Brennan PJ, Belisle JT (1996) Definition of the full extent of glycosylation of the 45-kilodalton glycoprotein of Mycobacterium tuberculosis. J Bacteriol 178:2498-2506

Dorokhov YL, Sheveleva AA, Frolova OY, Komarova TV, Zvereva AS, Ivanov PA, Atabekov JG (2007) Superexpression of tuberculosis antigens in plant leaves. Tuberculosis 87:218-224. https://doi.org/10.1016/j. tube.2006.10.001

Espitia C, Espinosa R, Saavedra R, Mancilla R, Romain F, Laqueyrerie A, Moreno C (1995) Antigenic and structural similarities between Mycobacterium tuberculosis 50- to 55-kilodalton and Mycobacterium bovis BCG 45- to 47-kilodalton antigens. Infect Immun 63:580-584

Ferraz JC, Stavropoulos E, Yang M, Coade S, Espitia C, Lowrie DB, Colston MJ, Tascon RE (2004) A heterologous DNA priming-Mycobacterium bovis BCG boosting immunization strategy using mycobacterial Hsp70, Hsp65, and Apa antigens improves protection against tuberculosis in mice. Infect Immun 72:6945-6950. https://doi.org/10.1128/IAI.72.12.6945-6950.2004
Fine PEM (2001) BCG: the challenge continues. Scand J Infect Dis 33:243-245. https://doi.org/10.1080/003655401300077144

Fischer R, Emans N (2000) Molecular farming of pharmaceutical proteins Transgenic Res 9:279-299 discussion 277

Fischer R, Schillberg S, Twyman RM (2009) Molecular farming of antibodies in plants. In: Recent advances in plant biotechnology. pp 35-63

Foley RC, Gao L-L, Spriggs A, Soo LYC, Goggin DE, Smith PMC, Atkins CA, Singh KB (2011) Identification and characterisation of seed storage protein transcripts from Lupinus angustifolius. BMC Plant Biol 11:59. https://doi. org/10.1186/1471-2229-11-59

Garapin A, Ma L, Pescher P, Lagranderie M, Marchal G (2001) Mixed immune response induced in rodents by two naked DNA genes coding for mycobacterial glycosylated proteins. Vaccine 19:2830-2841

González-Zamorano M, Mendoza-Hernández G, Xolalpa W, Parada C, Vallecillo AJ, Bigi F, Espitia C (2009) Mycobacterium tuberculosis glycoproteomics based on ConA-lectin affinity capture of mannosylated proteins. J Proteome Res 8:721-733. https://doi.org/10.1021/pr800756a

Hefferon KL (2012) Plant virus expression vectors set the stage as production platforms for biopharmaceutical proteins. Virology 433:1-6. https://doi. org/10.1016/j.virol.2012.06.012

Hernández-Velázquez A, López-Quesada A, Ceballo-Cámara Y, Cabrera-Herrera G, Tiel-González K, Mirabal-Ortega L, Pérez-Martínez M, Pérez-Castillo R, Rosabal-Ayán Y, Ramos-González O, Enríquez-Obregón G, Depicker A, Pujol-Ferrer M (2015) Tobacco seeds as efficient production platform for a biologically active anti-HBsAg monoclonal antibody. Transgenic Res 24:897-909. https://doi.org/10.1007/s11248-015-9890-8

Horn C, Namane A, Pescher P, Rivière M, Romain F, Puzo G, Bârzu O, Marchal G (1999) Decreased capacity of recombinant 45/47-kDa molecules (Apa) of Mycobacterium tuberculosis to stimulate T lymphocyte responses related to changes in their mannosylation pattern. J Biol Chem 274:32023-32030

Koncz C, Schell J (1986) The promoter of TL-DNA gene 5 controls the tissue-specific expression of chimaeric genes carried by a novel type of Agrobacterium binary vector. MGG Mol Gen Genet 204:383-396. https:// doi.org/10.1007/BF00331014

Kumar P, Amara RR, Challu VK, Chadda VK, Satchidanandam V (2003) The Apa protein of Mycobacterium tuberculosis stimulates gamma interferonsecreting CD4+ and CD8+T cells from purified protein derivativepositive individuals and affords protection in a guinea pig model. Infect Immun 71:1929-1937

Kuroda K, Brown EJ, Telle WB, Russell DG, Ratliff TL (1993) Characterization of the internalization of bacillus Calmette-Guerin by human bladder tumor cells.J Clin Invest 91:69-76. https://doi.org/10.1172/JCl116202

Laere E, Ling APK, Wong YP, Koh RY, Mohd Lila MA, Hussein S (2016) Plantbased vaccines: production and challenges. J Bot 2016:1-11. https://doi. org/10.1155/2016/4928637

Lakshmi PS, Verma D, Yang X, Lloyd B, Daniell H (2013) Low cost tuberculosis vaccine antigens in capsules: expression in chloroplasts, bio-encapsulation, stability and functional evaluation in vitro. PLOS ONE 8:e54708. https //doi.org/10.1371/journal.pone.0054708

Laqueyrerie A, Militzer P, Romain F, Eiglmeier K, Cole S, Marchal G (1995) Cloning, sequencing, and expression of the apa gene coding for the Mycobacterium tuberculosis 45/47-kilodalton secreted antigen complex. Infect Immun 63:4003-4010

Lara M, Servín-González L, Singh M, Moreno C, Cohen I, Nimtz M, Espitia C (2004) Expression, secretion, and glycosylation of the 45- and 47-kDa glycoprotein of Mycobacterium tuberculosis in Streptomyces lividans. Appl Environ Microbiol 70:679-685. https://doi.org/10.1128/ AEM.70.2.679-685.2004

Lee HS, Qi Y, Im W (2015) Effects of N-glycosylation on protein conformation and dynamics: protein Data Bank analysis and molecular dynamics simulation study. Sci Rep 5:8926. https://doi.org/10.1038/srep08926

Leite A, Kemper EL, Silva J, Luchessi AD, Siloto RMP, Bonaccorsi ED, El-dorry HF, Arruda P (2000) Expression of correctly processed human growth hormone in seeds of transgenic tobacco plants. Pharmacia 6:47-53

Ma JK-C, Drake P, Christou P (2003) The production of pharmaceutical proteins in plants. Nat Rev Genet 4:794-805

Maartens G, Wilkinson RJ (2007) Tuberculosis. Lancet 370:2030-2043. https:// doi.org/10.1016/S0140-6736(07)61262-8

Maliga P, Breznovits Á, Márton L (1973) Streptomycin-resistant plants from callus culture of haploid tobacco. Nat New Biol 244:29-30. https://doi. org/10.1038/newbio244029a0 
McCormick AA, Reddy S, Reinl SJ, Cameron TI, Czerwinkski DK, Vojdani F, Hanley KM, Garger SJ, White EL, Novak J, Barrett J, Holtz RB, Tuse D, Levy R (2008) Plant-produced idiotype vaccines for the treatment of non-Hodgkin's lymphoma: safety and immunogenicity in a phase I clinical study. Proc Natl Acad Sci 105:10131-10136. https://doi.org/10.1073/pnas.08036 36105

Murashige T, Skoog F (1962) A revised medium for rapid growth and bio assays with tobacco tissue cultures. Physiol Plant 15:473-497. https://doi. org/10.1111/j.1399-3054.1962.tb08052.x

Murray MG, Thompson WF (1980) Rapid isolation of high molecular weight plant DNA. Nucleic Acids Res 8:4321-4325

Norouzi S, Aghamohammadi A, Mamishi S, Rosenzweig SD, Rezaei N (2012) Bacillus Calmette-Guérin (BCG) complications associated with primary immunodeficiency diseases. J Infect 64:543-554. https://doi. org/10.1016/j.jinf.2012.03.012

Ottoboni LM, Leite A, Yunes JA, Targon ML, de Souza Filho GA, Arruda P (1993) Sequence analysis of $22 \mathrm{kDa}$-like alpha-coixin genes and their comparison with homologous zein and kafirin genes reveals highly conserved protein structure and regulatory elements. Plant Mol Biol 21:765-778

Peters J, Stoger E (2011) Transgenic crops for the production of recombinant vaccines and anti-microbial antibodies. Hum Vaccine 7:367-374

Ragas A, Roussel L, Puzo G, Rivière M (2007) The Mycobacterium tuberculosis cell-surface glycoprotein Apa as a potential adhesin to colonize target cells via the innate immune system pulmonary C-type lectin surfactant protein A. J Biol Chem 282:5133-5142. https://doi.org/10.1074/jbc.M6101 83200

Romain F, Laqueyrerie A, Militzer P, Pescher P, Chavarot P, Lagranderie M, Auregan G, Gheorghiu M, Marchal G (1993) Identification of a Mycobacterium bovis BCG 45/47-kilodalton antigen complex, an immunodominant target for antibody response after immunization with living bacteria. Infect Immun 61:742-750

Romain F, Horn C, Pescher P, Namane A, Riviere M, Puzo G, Barzu O, Marchal G (1999) Deglycosylation of the 45/47-kilodalton antigen complex of Mycobacterium tuberculosis decreases its capacity to elicit in vivo or in vitro cellular immune responses. Infect Immun 67:5567-5572

Rybicki EP (2017) Plant-made vaccines and reagents for the one health initiative. Hum Vaccines Immunother. 13:2912-2917

Sable SB, Cheruvu M, Nandakumar S, Sharma S, Bandyopadhyay K, Kellar KL, Posey JE, Plikaytis BB, Amara RR, Shinnick TM (2011) Cellular immune responses to nine Mycobacterium tuberculosis vaccine candidates following intranasal vaccination. PLOS ONE 6:e22718. https://doi.org/10.1371/ journal.pone.0022718

Schillberg S, Fischer R, Emans N (2003) Molecular farming of recombinant antibodies in plants. Cell Mol Life Sci 60:433-445

Scissum Gunn K, Singh N, Giambrone J, Wu H, Scissum-Gunn K (2012) Using transgenic plants as bioreactors to produce edible vaccines. J Biotech Res 4:1944-328592

Shukla AA, Thömmes J (2010) Recent advances in large-scale production of monoclonal antibodies and related proteins. Trends Biotechnol 28:253-261

Sinn HW, Elzey BD, Jensen RJ, Zhao X, Zhao W, Ratliff TL (2008) The fibronectin attachment protein of Bacillus Calmette-Guerin (BCG) mediates antitumor activity. Cancer Immunol Immunother 57:573-579. https://doi. org/10.1007/s00262-007-0397-x

Smith GT, Sweredoski MJ, Hess S (2014) O-linked glycosylation sites profiling in Mycobacterium tuberculosis culture filtrate proteins. J Proteomics 97:296-306. https://doi.org/10.1016/j.jprot.2013.05.011

Stöger E, Vaquero C, Torres E, Sack M, Nicholson L, Drossard J, Williams S, Keen D, Perrin Y, Christou P, Fischer R (2000) Cereal crops as viable production and storage systems for pharmaceutical scFv antibodies. Plant Mol Biol 42:583-590. https://doi.org/10.1023/A:1006301519427

Strasser R (2016) Plant protein glycosylation. Glycobiology 26:926-939. https:// doi.org/10.1093/glycob/cww023

WHO (2017) Global tuberculosis report 2017. WHO, Geneva

Woodard SL, Howard JA, Horn ME (2004) Plant molecular farming: systems and products. Plant Cell Rep 22:711-720. https://doi.org/10.1007/s0029 9-004-0767-1

Zelada AM, Calamante G, de la Paz Santangelo M, Bigi F, Verna F, Mentaberry A, Cataldi Á (2006) Expression of tuberculosis antigen ESAT-6 in Nicotiana tabacum using a potato virus X-based vector. Tuberculosis 86:263-267. https://doi.org/10.1016/j.tube.2006.01.003

Zeng XW, Zhang K, Li CY, Zhou Y, Bo L, Zhang XM, Hong YG (2008) Expression of highly immunogenic tuberculosis proteins in plants using a versatile Potato virus X- based expression system. J Hortic Sci Biotechnol 83:4-8. https://doi.org/10.1080/14620316.2008.11512339

Zhao W, Schorey JS, Bong-Mastek M, Ritchey J, Brown EJ, Ratliff TL (2000) Role of a Bacillus Calmette-Guérin fibronectin attachment protein in BCGinduced antitumor activity. Int J Cancer 86:83-88

\section{Submit your manuscript to a SpringerOpen ${ }^{\circ}$ journal and benefit from:}

- Convenient online submission

- Rigorous peer review

- Open access: articles freely available online

- High visibility within the field

- Retaining the copyright to your article

Submit your next manuscript at springeropen.com 